\title{
Pengaruh Country of Origin Dan Celebrity Endorser Terhadap Keputusan Pembelian Pada Produk Nature Republic Aloe Vera 92\% Shooting Gel
}

\author{
Vira Rizky Septiani, Riska Nur Oktavia, dan Ajat Sudrajat \\ Universitas Singaperbangsa, Karawang \\ viraaa899@gmail.com, riskanur@gmail.com, ${ }^{3}$ ajat.sudrajat@fe.unsika.ac.id
}

\begin{abstract}
Abstrak
Penelitian ini dilakukan untuk mengatuhui pengaruh variabel country of origin dan celebrity endorser terhadap keputusan pembelian pada produk nature republic aloe vera $92 \%$ shooting gel. Pada penelitia ini menggunakan metode deskriptif dan verifikatif dan pada penelitian ini pengumpulan data dilakukan dengan menyebarkan kuesioner kepada 100 responden yang merupakan konsumen nature republic aloe vera $92 \%$ shooting gel. Teknik sampling menggunakan simple random sampling. Hasil penelitian ini diketahui bahwa terdapat pengaruh country of origin terhadap keputusan pembelian produk nature republic aloe vera $92 \%$ shooting gel sebesar $36,9 \%$ dan country of origin memiliki kontribusi sebesar $20,6 \%$ terhadap keputusan pembelian. Terdapat pengaruh celebrity endorser terhadap keputusan pembelian produk Nature Republic Aloe Vera 92\% Shooting Gel sebesar 30,5\% dan celebrity endorser memiliki kontribusi sebesar 16,3\% terhadap keputusan pembelian. Dan terdapat pengaruh simultan dari country of origin dan celebrity endorser terhadap keputusan pembelian. Total pengaruh country of origin dan celebrity endorser memiliki kontribusi terhadap keputusan pembelian sebesar $36,9 \%$.
\end{abstract}

Kata kunci: Pemasaran, Country of Origin, Celebrity Endorser

\begin{abstract}
This research was conducted to find out the influence of country of origin and celebrity endorser variables on purchasing decisions on aloe vera nature republic products $92 \%$ shooting gel. In this study using descriptive and verification methods and in this study data collection was carried out by distributing questionnaires to 100 respondents who are consumers of nature republic aloe vera 92\% shooting gel. The sampling technique uses simple random sampling. The results of this study note that there is an influence of country of origin on the purchase decision of nature republic's products aloe vera $92 \%$ shooting gel of $36.9 \%$ and country of origin has a contribution of $20.6 \%$ on the purchase decision. There is an influence of celebrity endorser on the purchase decision of Nature Republic Aloe Vera 92\% Shooting Gel product at 30.5\% and celebrity endorser has a contribution of $16.3 \%$ on the purchase decision. And there are simultaneous influences from country of origin and celebrity endorser on purchasing decisions. The total influence of country of origin and celebrity endorsers contributed to the buying decision of $36.9 \%$.
\end{abstract}

Keywords: Marketing, Country of Origin, Celebrity Endorser 


\section{PENDAHULUAN}

Seiring dengan berkembangnya zaman, kini kebutuhan manusia semakin beragam. Salah satu kebutuhan yang sulit dipisahkan dari manusia adalah kosmetik. Kosmetik adalah bahan yang digunakan untuk tubuh bagian luar manusia dari ujung rambut hingga ujung kaki yang bertujuan untuk mempercantik, menyehatkan, membersihkan dan melindungi tubuh pada kondisi yang baik. Ada berbagai macam produk kosmetik pada umumnya yaitu skincare, bodycare dan haircare.

Terus meningkatnya penjualan kosmetik di Indonesia membuat banyak pemilik perusahaan industri kosmetik asing menjadikan Indonesia sebagai peluang untuk memperluas pasarnya. Hal tersebut membuat banyak sekali merek kosmetik asing masuk dan berkembang di pasar kosmetik Indonesia. Sehingga membuat konsumen terbiasa dan mulai lebih menyukai produk kosmetik asing dibandingkan produk kosmetik lokal.

Kosmetik asal Korea Selatan menjadi pilihan banyak para pecinta produk kecantikan. Data dari ZAP Beauty Index 2018 terhadap 17.889 perempuan mengungkapkan, sebanyak 46,6 persen perempuan paling suka produk asal negeri ginseng (Kompas.com, 2018). Banyak sekali produk asal Korea Selatan yang sudah masuk dan berkembang di Indonesia, salah satunya adalah produk Nature Republic Aloe Vera 92\% Shooting Gel. Produk asal Korea Selatan tersebut kini sudah banyak ditemukan baik di store resmi yang sudah tersebar di kota-kota besar di Indonesia, bahkan di toko-toko kosmetik kecil baik pada toko kosmetik online maupun toko kosmetik offline. Salah satunya adalah Karawang. Saat ini Nature Republic sudah banyak ditemukan di kota Karawang, baik itu di gerai kosmetik pada mall-mall yang ada di Karawang ataupun di toko kosmetik yang tersebar di Karawang.

Menurut Kotler dan Keller (2009) keputusan pembelian adalah keputusan konsumen terhadap merek terpilih diantara kumpulan pilihan merek-merek yang ada. Juga menurut Schiffman dan Kanuk (2009), keputusan pembelian yaitu pemilihan dari dua atau lebih alternatif pilihan keputusan pembelian, artinya bahwa seseorang bisa membuat keputusan, harus tersedia beberapa alternatif pilihan. Keputusan untuk membeli bisa mengarah pada bagimana proses dalam pengambilan keputusan tersebut itu dilakukan. Keputusan pembelian konsumen dipengaruhi oleh perilaku konsumen, dan dalam pengambilan keputusanya terdapat beberapa faktor yang mempengaruhi perilaku konsumen.

Menurut Kotler dan Keller (2009) Country of Origin adalah asosiasi dan kepercayaan mental seseorang akan suatu produk yang dipicu oleh negara asal produk. Country of Origin dapat mempengaruhi perilaku konsumen dalam pengambilan keputusan pembelian suatu produk.

Faktor lain yang dapat mempengaruhi keputusan pembelian adalah Celebrity Endorser. Celebrity Endorser merupakan ikon atau sering disebut juga sebagai sumber langsung untuk mengantarkan sebuah pesan dan atau memperagakan sebuah produk atau jasa dalam kegiatan promosi yang bertujuan untuk mendukung efektifitas penyampaian pesan produk (Belch dan Belch dalam Ofori-Okyere, 2015). Juru bicara yang dianggap serupa dengan penonton diharapkan memiliki efek paling besar dalam mempengaruhi sikap dan keputusan pembelian mereka (Shimp, 2014) . Oleh karena itu, pemilihan Celebrity Endorser yang tepat diharapkan mampu menarik perhatian konsumen serta untuk meningkatkan jumlah penjualan produk barang atau jasa sesuai target yang ditetapkan perusahaan (Susanti, 2017).

Rumusan masalah pada penelitian ini dibuat dalam bentuk pertanyaan dibawah ini :

1. Seberapa besar korelasi antara Country of Origin dan Celebrity Endorser terhadap Pada Nature Republic Aloe Vera 92\% Shooting Gel?

2. Seberapa besar pengaruh parsial Country of Origin dan Celebrity Endorser terhadap Keputusan Pembelian pada Nature Republic Aloe Vera 92\% Shooting Gel?

3. Seberapa besar pengaruh simultan Country of Origin dan Celebrity Endorser terhadap Keputusan Pembelian Nature Republic Aloe Vera $92 \%$ Shooting Gel?

Penelitian ini bertujuan untuk:

1. Untuk mengetahui, menganalisis dan menjelaskan korelasi antara Country of Origin dan Celebrity Endorser pada produk Nature Republic Aloe Vera 92\% Shooting Gel.

2. Untuk mengetahui, menganalisis dan menjelaskan pengaruh parsial antara Country of Origin dan Celebrity Endorser terhadap Keputusan Pembelian produk Nature Republic Aloe Vera 92\% Shooting Gel. 
3. Untuk mengetahui, menganalisis dan menjelaskan pengaruh simultan antara Country of Origin dan Celebrity Endorser

terhadap Keputusan Pembelian produk Nature Republic Aloe Vera 92\% Shooting Gel.

Manfaat dalam penelitian ini sebagai berikut :

1. Dengan diketahuinya korelasi, pengaruh parsial dan pengurah simultan dari Country of Origin dan Celebrity Endorser terhadap Keputusan Pembelian produk Nature Republic Aloe Vera $92 \%$ Shooting Gel maka akan bermanfaat secara teoritis untuk menambah dan memperdalam pengetahuan bagi perkembangan ilmu ekonomi manajemen khususnya manajemen pemasaran. Maka penelitian ini diharapkan dapat dapat memberikan sumbangan dalam aspek teoritis (keilmuan), melalui pendekatan-pendekatan baru dalam aspek manajemen pemasaran mengenai pengaruh Country of Origin dan Celebrity Endorser terhadap Keputusan Pembelian, sehingga penelitian ini dapat memberikan sumbangan bagi akademis dalam

mengembangkan teori manajemen pemasaran.

2. Dengan diketahuinya korelasi, pengaruh parsial dan pengaruh simultan dari Country of Origin dan Celebrity Endorser terhadap Keputusan Pembelian produk Nature Republic Aloe Vera 92\% Shooting Gel maka akan bermanfaat secara praktis untuk dapat dipakai sebagai bahan pertimbangan bagi pihak Universitas dalam menganalisis pengaruh Country of Origin dan Celebrity Endorser terhadap Keputusan Pembelian produk Nataure Republic Aloe Vera 92\% Shooting Gel. Penelitian ini juga diharapkan dapat memberikan sumbangan dalam aspek praktis (guna laksana) yaitu memberikan sumbangan pemikiran bagi pihak perusahaan Nature Republic sebagai bahan pengambilan kebijakan pengelolaan dalam menganalisis pemasaran produknya untuk meningkatkan penjualan produk.

\section{METODE}

Pada penelitia ini menggunakan metode deskriptif dan verifikatif. Metode deskriptif dilakukan untuk mengemukakan data yang masuk dengan cara dikelompokkan dan ditabulasikan, kemudian hasilnya diberikan penjelasan. Metode deskriptif digunakan untuk mengetahui gambaran mengenai country of origin, celebrity endorser, dan keputusan pembelian pada produk Nature Republic Aloe Vera 92\% Shooting Gel. Sedangkan metode verifikatif dilakukan untuk mengukur suatu fenomena penelitian dengan menggunakan alat bantu statistik. Adapun metode statistik yang digunakan untuk menganalisis hubungan antar variabel yang diteliti yaitu dengan menggunakan analisis jalur (path analysis) untuk menguji pengaruh secara parsial/individual dan keseluruhan dari variabel bebas (independent) terhadap variabel terikat (dependent).

Pada penelitian ini pengumpulan data dilakukan dengan menyebarkan kuesioner; yaitu teknik pengumpulan data dengan mengirimkan beberapa pernyataan kepada responden. Masing-masing item jawaban disediakan beberapa alternatif jawaban yang disusun berdasarkan Skala Likert dengan rentang skala 1 (satu) sampai dengan 5 (lima) yang artinya 1

(satu) yaitu Sangat Tidak Setuju (STS), 2 (dua) Tidak Setuju (TS), 3 (tiga) Cukup Setuju (CS), 4 (empat) yaitu Setuju (S) dan 5 (lima) yaitu Sangat Setuju (SS). Sementara jumlah sampel sebanyak 100 orang responden dari populasi sebanyak 1.815 orang. Teknik sampling menggunakan Simple Random Sampling. Dikatakan simple (sederhana) karena pengambilan anggota sampel dari populasi dilakukan secara acak tanpa memperhatikan strata yang ada dalam populasi itu. Sampel pada penelitian ini adalah Mahasiswa Universitas Singaperbangsa Karawang Fakultas Ekonomi dan Bisnis. Penelitian dilakukan di Fakultas Ekonomi dan Bisnis Univeristas Singaperbangsa Karawang yang beralamt di JL. HS Ronggowaluyo, Puseurjaya, Kec. Telukjambe Timur Kab. Karawang.

\section{HASIL DAN PEMBAHASAN KARAKTERISTIK RESPONDEN}

Karakteristik berdasarkan jenis kelamin terdiri dari 19 orang (19\%) laki-laki dan 81 orang (81\%) perempuan. Hal ini menujukkan bahwa jumlah responden perempuan jauh lebih banyak dibandingkan dengan responden laki-laki. Berdasarkan golongan usia dapat dijelaskan bahwa responden yang berusia $<20$ tahun sebanyak 42 orang (42\%) dan responden yang berusia 20-25 tahun sebanyak 58 orang (58\%). Hal ini menunjukkan bahwa responden terbanyak adalah yang berusia 20-25 tahun yaitu sebanyak 58 orang dengan presentase $58 \%$. Berdasarkan pendapatan dapat dijelaskan bahwa responden 
yang memiliki pendapatan < Rp 500.000,sebanyak 54 orang (54\%), responden yang memiliki pendapatan Rp. 500.000,- s/d Rp. 2.000.000,- sebanyak 39 orang (39\%) dan responden yang memiliki pendapatan $>\mathrm{Rp}$. 2.000.000,- sebanyak 7 orang (7\%). Hal ini menunjukkan bahwa responden terbanyak adalah yang memiliki pendapatan $<\mathrm{Rp} 500.000$,-

- Berdasarkan frekuensi pembelian dapat dijelaskan bahwa responden yang membeli secara rutin sebanyak 15 orang (15\%), responden yang membeli dengan frekuensi sering sebanyak 3 orang (3\%) dan responden yang membeli dengan frekuensi kadang-kadang sebanyak 82 orang ( $82 \%)$.

\section{UJ KEABSAHAN DATA UJI VALIDITAS}

Menurut Sugiyono (2012), item yang mempunyai korelasi positif dengan skor total serta korelasi tertinggi menunjukkan bahwa item tersebut dapat dianggap valid apabila $r=0,30$ sehingga apabila korelasi antar item dengan skor item total kurang dari 0,3 maka item instrument tersebut dinyatakan tidak valid.

Hasil uji validitas variabel country of origin dengan keseluruhan item pernyataan sebanyak 8 item dinyatakan valid karena nilai $r$ hitung lebih besar dari pada nilai $r$ kritis $(0,3)$.

Hasil uji validitas variabel celebrity endorser dengan kesuluruhan item pernyataan sebanyak 15 item dinyatakan valid karena nilai $r$ hitung lebih besar dari pada $r$ kritis $(0,3)$.

Hasil uji validitas variabel keputusan pembelian dengan keseluruhan item pernyataan sebanyak 13 item dinyatakan valid karena nilai $r$ hitung lebih besar dari pada $r$ kritis $(0,3)$.

\section{UJI RELIABILITAS}

Uji reliabilitas digunakan untuk
mengukur keakuratan, kestabilan, dan konsistensi suatu instrument penelitian. Untuk menilai apakah reliabel atau tidak instrumen, dilakukan dengan mengkonsultasikan hasil perhitungan alpha cronbach dengan angka $r$ product moment. Jika diperoleh $r$ hitung (koefisien alpha cronbach) lebih besar daripada $r$ tabel, maka instrumen tersebut dinyatakan reliabel. Sebaliknya jika $r$ hitung (koefisien alpha cronbach) lebih kecil dari $r$ tabel, maka instrumen tersebut dinyatakan tidak reliabel (Arikunto, 2010).
Berdasarkan hasil uji reliabilitas pada penelitian ini diperoleh $r$ hitung (koefisien alpha cronbach) variabel country of origin sebesar 0,859 , variabel celebrity endorser sebesar 0,913 dan variabel keputusan pembelian sebesar 0,897, maka nilai $r$ hitung (koefisien alpha cronbach) untuk setiap variabel lebih besar dari $r$ tabel $(0,60)$ sehingga variabel country of origin $\left(X_{1}\right)$, variabel celebrity endorser $\left(X_{2}\right)$ dan variabel keputusan pembelian $(\mathrm{Y})$ dinyatakan reliabel.

\section{UJ NORMALITAS}

Uji normalitas ini dapat juga dilakukan dengan melakukan pengujian kolmogorof Smirnov dengan dasar pengambilan keputusan yakni: jika nilai signifikansi lebih besar dari 0,05 maka data tersebut berdistribusi normal. Sebaliknya, jika nilai signifikansi lebih kecil dari 0,05 maka data tersebut tidak berdistribusi normal (Hamdi \& E Bahrudin, 2014).

Berdasarkan hasil uji normalitas pada penelitian ini diketahui nilai signifikansi variabel country of origin sebesar 0,315 , variabel celebrity endorser sebesar 0,926 dan variabel keputusan pembelian sebesar 0,654 menunjukan bahwa semua variabel mengikuti sebaran data normal karena nilai signifikan a hitung semua variabel lebih dari 0,05 . Maka semua variabel dinyatakan mengikuti sebaran data normal.

\section{TEKNIK ANALISIS DATA ANALISIS DESKRIPTIF}

Berdasarkandata deskriptif menunjukkan bahwa variabel Country of Origin berada pada skala Setuju artinya para konsumen sebagai responden menunjukkan respon yang baik atas persepsi Country of Origin pada produk Nature Republic Aloe Vera 92\% Shooting Gel. Sedangkan untuk variabel Celebrity Endorser berada pada skala Setuju artinya para konsumen sebagai responden menunjukkan respon yang baik terhadap Celebrity Endorser pada produk Nature Republic Aloe Vera 92\% Shooting Gel. Sedangkan untuk variabel Keputusan Pembelian berada pada skala Setuju artinya para konsumen sebagai responden menunjukkan respon yang baik atas Keputusan Pembelian pada produk Nature Republic Aloe Vera 92\% Shooting Gel. 


\section{ANALISIS VERIFIKATIF}

Dalam penelitian ini analisis verifikatif bermaksud untuk mengetahui hasil penelitian yang berkaitan dengan pengaruh atau besarnya dampak Country of Origin, Celebrity Endorser, dan Keputusan Pembelian Nature Republic Aloe Vera $90 \%$ Shooting Gel survei pada Mahasiswa Universitas Singaperbangsa Karawang Fakultas Ekonomi dan Bisnis. Dengan metode ini dapat diketahui berapa besarnya dampak variabel independent mempengaruhi terhadap variabel dependent. Adapun analisis verifikatif dalam penelitian ini menggunakan Analisis Jalur (Path Analysis).

Tabel 1. Regresi Antara Variabel Country of

Origin dan Celebrity Endorser Terhadap Keputusan Pembelian Coefficients $^{a}$

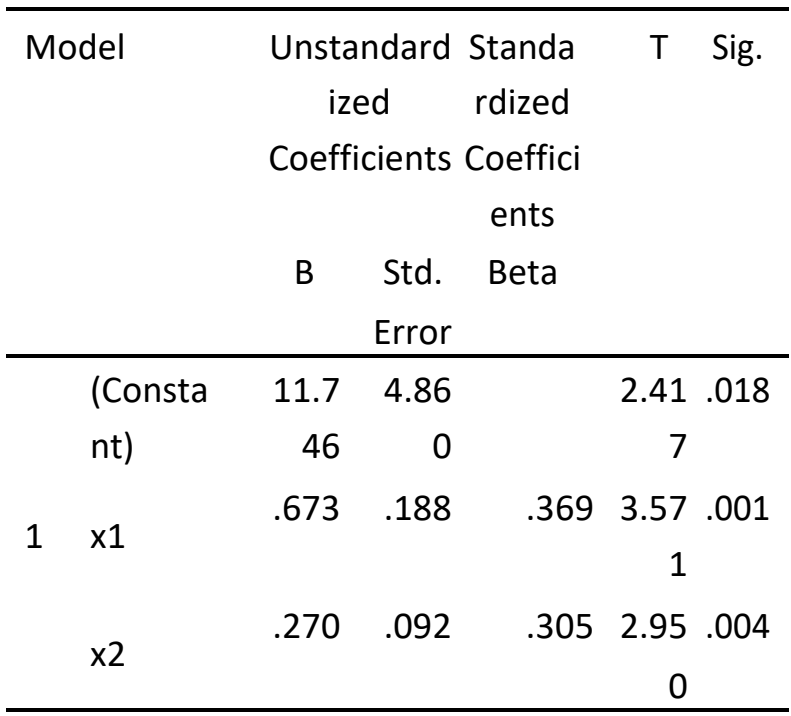

a. Dependent Variable: $y$

Sumber : Pengolahan Data SPSS, Peneliti 2019 Berdasarkan Tabel di atas menunjukkan

nilai koefisien jalur antara variabel country of origin dan celebrity endorser terhadap keputusan pembelian.

Koefisien jalur variabel $\left(X_{1}\right)$ dan $\left(X_{2}\right)$ terhadap variabel $(\mathrm{Y})$ dapat digambarkan seperti dibawah ini :

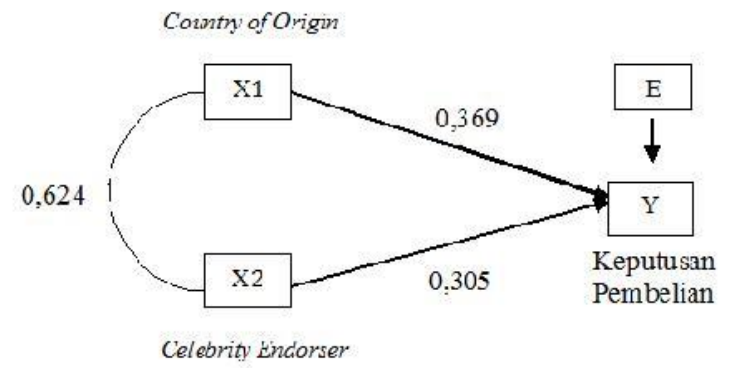

\section{Gambar 1. Pengaruh Variabel Country of Origin dan Celebrity Endorser Terhadap Keputusan Pembelian}

Sumber : Pengolahan Data SPSS, Peneliti 2019 Berdasarkan Gambar 1 menunjukkan

bahwa besaran derajat positif asosiatif atau koefisien jalur variabel country of origin $(0,369)$ lebih tinggi dari variabel celebrity endorser $(0,305)$, artinya country of origin $\left(X_{1}\right)$ lebih berpengaruh terhadap keputusan pembelian $(Y)$ dibandingkan dengan celebrity endorser $\left(X_{2}\right)$. Adapun persamaan jalurnya adalah sebagai berikut : $Y=0,369 X_{1}+0,305 X_{2}+\varepsilon$

Pengaruh langsung dan tidak langsung secara bersamaan dari variabel country of origin $\left(X_{1}\right)$ dan celebrity endorser $\left(X_{2}\right)$ terhadap keputusan pembelian ( $\mathrm{Y}$ ) adalah sebagai sebagai berikut :

Tabel 2. Pengaruh Langsung dan Tidak Langsung Variabel Bebas dan Variabel Terikat Terhadap

\begin{tabular}{|c|c|c|c|c|c|}
\hline \multirow[t]{2}{*}{ Variabel } & \multirow[t]{2}{*}{$\begin{array}{l}\text { Koefisien } \\
\text { Jalur }\end{array}$} & \multirow[t]{2}{*}{$\begin{array}{l}\text { Pengaruh } \\
\text { Langsung }\end{array}$} & \multicolumn{2}{|c|}{$\begin{array}{l}\text { Pengaruh } \\
\text { Tidak } \\
\text { Langsung }\end{array}$} & \multirow[t]{2}{*}{$\begin{array}{l}\text { Subtotal } \\
\text { Pengaruh }\end{array}$} \\
\hline & & & $X_{1}$ & $X_{2}$ & \\
\hline $\begin{array}{l}\text { Country } \\
\text { of Origin }\end{array}$ & 0,369 & 0,136 & - & 0,070 & 0,206 \\
\hline $\begin{array}{l}\text { Celebrity } \\
\text { Endorser }\end{array}$ & 0,305 & 0,093 & 0,070 & - & 0,163 \\
\hline \multicolumn{5}{|c|}{ Total Pengaruh } & 0,369 \\
\hline \multicolumn{5}{|c|}{ Pengaruh Variabel Lain $(\varepsilon)$ Epsilon } & 0,631 \\
\hline
\end{tabular}

Sumber : Pengolahan Data SPSS, Peneliti 2019 Pada Tabel di atas menunjukkan bahwa

country of origin $\left(\mathrm{X}_{1}\right)$ memiliki kontribusi tehadap keputusan pembelian $(Y)$ yaitu sebesar 0,206 atau $20,6 \%$. Sedangkan celebrity endorser $\left(X_{2}\right)$ memiliki kontribusi terhadap keputusan pembelian $(\mathrm{Y})$ yaitu sebesar 0,163 atau $16,3 \%$. Pengaruh yang disebabkan country of origin $\left(X_{1}\right)$ dan celebrity endorser $\left(\mathrm{X}_{2}\right)$ terhadap keputusan pembelian $(\mathrm{Y})$ yaitu sebesar 0,369 atau $36,9 \%$. Adapun pengaruh variabel lain diluar model adalah sebesar $1-0,369=0,631$ atau $63,1 \%$.

\section{PENGUJIAN HIPOTESIS}

Untuk menguji secara parsial antara variabel bebas dengan variabel terikat, dapat dilihat pada tabel berikut ini : 
Tabel 3. Hasil Analisis Jalur Secara Parsial

\begin{tabular}{cccccc}
\hline Struktural & Sig. & $\mathbf{A}$ & $\begin{array}{c}\mathbf{t} \\
\text { hitung }\end{array}$ & $\begin{array}{c}\mathbf{t} \\
\text { tabel }\end{array}$ & Kesimpulan \\
\hline $\mathrm{\rho yx}_{1}$ & 0,001 & 0,10 & 3,571 & 1,290 & $\mathrm{H}_{0}$ ditolak \\
$\mathrm{\rho yx}_{2}$ & 0,004 & 0,10 & 2,950 & 1,290 & $\mathrm{H}_{0}$ ditolak \\
\hline
\end{tabular}

Sumber : Pengolahan Data SPSS, Peneliti 2019

Berdasarkan tabel di atas didapat hasil

sebagai berikut :

a. Untuk pengaruh $\mathrm{X}_{1}$ terhadap $\mathrm{Y}$, nilai sig $(0,001)<a(0,10)$ dan $t$ hitung $(3,571)>t$ tabel $(1,290)$ maka $\mathrm{H}_{0}$ ditolak.

b. Untuk pengaruh $\mathrm{X}_{2}$ terhadap $\mathrm{Y}$, nilai sig $(0,004)<\mathrm{a}(0,10)$ dan $\mathrm{t}$ hitung $(2,950)>\mathrm{t}$ tabel $(1,290)$ maka $\mathrm{H}_{0}$ ditolak.

Untuk menguji secara parsial antara variabel

bebas dengan variabel terikat, dapat dilihat pada tabel berikut ini :

Tabel 4. Hasil Analisis Jalur Secara Simultan

\begin{tabular}{llcccc}
\hline Struktur & Sig. & A & $\begin{array}{c}\text { F } \\
\text { Hitung }\end{array}$ & $\begin{array}{c}\text { F } \\
\text { Tabel }\end{array}$ & Kesimpulan \\
& & & &
\end{tabular}

$\begin{array}{llllll}\text { pyx }_{1} x_{2} & 0,000 & 0,10 & 28,345 & 2,36 & H_{0} \text { Ditolak }\end{array}$

Sumber : Pengolahan Data SPSS, Peneliti 2019 Berdasarkan tabel di atas didapat hasil menunjukkan nila Sig. $(0,000)<a(0,10)$ dan $f$ hitung $(28,345)>f$ tabel $(2,36)$ maka Ho ditolak. Dengan demikian dapat disimpulkan bahwa Country of Origin dan Celebrity Endorser berpegaruh simultan terhadap keputusan pembelian.

\section{SIMPULAN}

Berdasarkan penelitian yang telah dilakukan maka simpulan yang dapat diambil mengenai Country of Origin dan Celebrity Endorser terhadap Keputusan Pembelian produk Nature Republic Aloe Vera 92\% Shooting Gel adalah sebagai berikut :

1. Berdasarkan hasil penelitian menunjukkan bahwa keputusan pembelian pada produk Nature Republic Aloe Vera 92\% Shooting Gel berdasarkan hasil kuesioner diperoleh skala Setuju. Hal ini menunjukkan bahwa perusahaan berhasil dalam memberikan kemudahan dalam proses pengambilan keputusan pembelian pada produk Nature Republic Aloe Vera 92\% Shooting Gel.

2. Berdasarkan hasil penelitian menunjukkan bahwa persepsi country of origin pada produk Nature Republic Aloe Vera 92\%
Shooting Gel berdasarkan hasil kuesioner diperoleh skala Setuju. Artinya persepsi konsumen mengenai country of origin pada pembelian produk Nature Republic Aloe Vera $92 \%$ Shooting Gel sudah baik.

3. Berdasarkan hasil penelitian menunjukkan bahwa celebrity endorser produk Nature Republic Aloe Vera 92\% Shooting Gel berdasarkan hasil kuesioner berada pada skala Setuju. Artinya perusahaan berhasil memilih endorser yang tepat yang mampu menarik perhatian konsumen serta dapat dipercaya oleh konsumen Nature Republic Aloe Vera 92\% Shooting Gel.

4. Terdapat pengaruh parsial dari country of origin dan celebrity endorser terhadap keputusan pembelian dengan rincian sebagai berikut :

a. Terdapat pengaruh country of origin terhadap keputusan pembelian produk Nature Republic Aloe Vera 92\% Shooting Gel sebesar sebesar 36,9\% dan country of origin memiliki kontribusi sebesar 20,6\% terhadap keputusan pembelian.

b. Terdapat pengaruh celebrity endorser terhadap keputusan pembelian produk Nature Republic Aloe Vera 92\% Shooting Gel sebesar 30,5\% dan celebrity endorser memiliki kontribusi sebesar 16,3\% terhadap keputusan pembelian.

5. Terdapat pengaruh simultan dari country of origin dan celebrity endorser terhadap keputusan pembelian. Total pengaruh country of origin dan celebrity endorser memiliki kontribusi terhadap keputusan pembelian sebesar 36,9\% sedangkan sisanya 63,1\% merupakan kontribusi variabel $(\varepsilon)$ yang tidak diteliti. Hal ini menunjukkan bahwa country of origin dan celebrity endorser sama-sama memiliki pengaruh terhadap keputusan pembelian konsumen. 


\section{DAFTAR PUSTAKA}

[1] Anna, L. K., \& Kompas.com. (2018). Korea Selatan Masih Jadi Kiblat Kecantikan Wanita Indonesia. Retrieved October 2, 2019, from www.kompas.com website: https://amp.kompas.com/lifestyle/read/ 2018/08/20/173500420/korea-selatanmasih-jadi-kiblat-kecantikan-wanitaindonesia\#treferrer=https://www.google. com

[2] Arikunto, S. (2010). Prosedur Penelitian: Suatu Pendekatan Praktik. Jakarta: Bineka Cipta.

[3] Hamdi, \& E, B. (2014). Model Penelitian Kuantitatif Aplikasi dalam Pendidikan. Edisi 1. Cetakan 1. Yogyakarta: Deepublish.

[4] Kotler, P., \& Keller. (2009). Manajemen Pemasaran Jilid 1 Edisi 13. Jakarta: Erlangga.

[5] Schiffman, \& Kanuk. (2009). Perilaku Konsumen Edisi 7. Jakarta: Indeks.

[6] Shimp, T. A. (2014). Komunikasi Pemasaran Terpadu dalam Periklanan dan Promosi Edisi 8. Alih bahasa oleh Harya Bhima Sena. Jakarta: Salemba Empat.

[7] Sugiyono. (2012). Stastika Untuk Penelitian. Bandung: Alfabeta.

[8] Susanti, W. (2017). Pengaruh Atribut Produk Dan Celebrity Endorser Terhadap Keputusan Pembelian Busana Muslim (Survei Pada Pelanggan Zoya Karawang). 